\title{
Chapter 3 \\ Tigers at Critical Junctures: How South \\ Korea, Taiwan and Singapore Survived \\ Growth-Led Conflicts
}

\author{
Veerayooth Kanchoochat
}

\subsection{Catch-up and Conflicts}

Early studies on the developmental state examined the characteristics of East Asian economies that, despite deviating from the conventional free-market model, succeeded in catching up with the developed world within a few decades after the Second World War. The general consensus is that developmental states are those that possessed: a centralized state structure; effective and autonomous bureaucracy; and a close and productive relationship between states and industries (Johnson 1982; Amsden 1989; Wade 1990; Evans 1995). Most states in the developing world do not share such characteristics and are thereby incapable of achieving economic performance of the East Asian calibre (see Evans and Rauch 1999). However, an agenda following this strand of studies is clear: enhancing state capacity is key to sustaining long-term economic growth.

Although the developmental state literature provides us with an alternative set of development model and policy choices, it understates one critical aspect of the catchup process, that is, conflict. Take Thailand, Brazil and Turkey, for example. These three countries were promising economies in their respective regions and were on the verge of reaching a high-income level following East Asian tigers - if they maintained their growth momentum for another decade or so. Thailand was once the world's fastest-growing economy between 1987 and 1996, with the average annual growth rate of real GDP per capita at $9.5 \%$. Brazil flourished during the Lula presidency (2003-10), with its praiseworthy attempts to maintain macroeconomic stability and to reduce inequality through effective social policies. Turkey was a thriving uppermiddle-income country in the early 2000s when its poverty headcount ratio halved within a decade.

\footnotetext{
V. Kanchoochat ( $\square)$

National Graduate Institute for Policy Studies (GRIPS), Tokyo, Japan

e-mail: kanchoochat@grips.ac.jp 
Nonetheless, what these three countries have in common in the 2010s are a string of violent confrontations between conflictual groups in society. The state capacity of these three countries may increase with the passage of time, but their impenetrable barrier seems to lie in the realm of socio-political conflict-the issue that is overlooked in the traditional developmental state literature. Have South Korea, Taiwan and Singapore undergone economic transformations with neither social nor political conflict?

Actually, economic catch-up is, by its very nature, a contentious process laden with political and social conflicts along the way. As Kuznets (1972) pointed out, technological development that characterizes modern economic growth and a structural change process inevitably leads to dislocation of productive factors, making the process extremely conflictual. If factors of production are perfectly mobile, as in theory, this should not cause a problem. However, when the mobility of certain physical and human assets is limited, as is the case in the real world, their owners face the prospect of obsolescence and induce them to take non-market or political actions to redress the situation (e.g. petitions, strikes, bribing). Therefore, the process of structural change will be full of conflict and generate pressures for an explicitly political management of the economy by the state (Chang 1994, 302). Without the effective role of the state and institutions of conflict management, socio-political conflict not only diverts resources away from economically productive activities but also discourages such activities as a result of the uncertainty it generates (Rodrik 2008, 161).

The growth-led conflict could be even more detrimental in the developmental states, whose ruling elite tends to favor certain social forces (e.g. capitalist and bureaucratic) over others (e.g. labor and peasant). To understand successful catch-up more fully, the process of developmental state building should not simply be seen as a story about effective economic policies implemented by capable states. An equally important, but far less explored, dimension is how East Asian states "managed" the socio-political conflicts that accompanied their rapid economic transformation. This puzzle forms the key question of this chapter: How have the East Asian states (South Korea, Taiwan and Singapore) dealt with the domestic conflicts arising from their catch-up process?

\subsubsection{The Argument}

Economic development in East Asia has been neither smooth nor harmonious. Conflict has been an integral part of their growth and created dangerous tensions from time to time. This chapter seeks to underline the growth-led conflicts in the East Asian tigers and discusses the implications that are relevant to today's emerging economies.

It argues that the characteristics of growth-led conflict vary across countries. The diversity within the East Asian development models is key to understanding the multiplicity of these conflicts as well as the way in which each country reached 
a socio-political "settlement". ${ }^{1}$ South Korea has undergone a series of contentious settlements, in which opposing forces clashed for a few decades before reaching a compromise. Taiwan has pursued a gradual process of political opening in which competing groups of elite reached an agreement. A distinctive trajectory of continuous consolidation is found in Singapore, whereby interests and ideologies among the ruling party, key government agencies and the middle class have been readjusted periodically to maintain their symbiotic relationship.

Existing analyses usually highlight the common features of the East Asian model, pointing to the export-oriented industrialization and quality human resources. This statement may not be wrong per se, but it does overlook the varieties within; and it is such varieties of catch-up strategy that shape the subsequent path to settlement. South Korea was single-minded on growth and driven by a small circle of large conglomerates. Taiwan pursued a growth-with-equity strategy from the start, with the intention of nurturing small and medium-sized enterprises (SMEs). Singapore mixed the use of state-owned enterprises (SOEs) and interventionist social policies with free trade and foreign investment. These varied strategies have led each one to different economic outcomes and have a significant bearing upon each country's pattern of socio-political settlement in the later phase of catch-up.

The following sections explore the empirical cases of South Korea, Taiwan and Singapore respectively. The conclusion summarizes the findings on the varieties of catch-up strategy and multiple paths to settlement, and discusses a broader implication that goes beyond a conventional wisdom on liberal democracy.

\subsection{South Korea and Contentious Settlements}

The settlement process in South Korea is characterized by confrontation and fragmentation. Its catch-up strategy, led by General Park Jung Hee, produced relatively clear-cut winners and losers. Confrontation began as early as the start of the catchup, but became more intense in the late 1980s, in which the mass protestors forced the military to grant a direct presidential election in 1987. Yet, fragmentation within pro-democracy movements paved the way for the electoral success of the militarybacked candidate. Contentious politics have continued alongside political opening until recently.

\footnotetext{
${ }^{1}$ A socio-political settlement has narrow and broad definitions. A narrow one is defined by the UK Department for International Development (DFID) as "the forging of a common understanding, usually between political elites, that their best interests or beliefs are served through acquiescence to a framework for administering political power" (cited in Di John and Putzel 2009: 4). This chapter follows a broader definition that considers political settlement as "social order based on political compromises between powerful groups in society that sets the context for institutional and other policies" (Khan 2010, 4).
} 


\subsubsection{Catch-up Strategy: Chaebol-Led Growth}

After the Korean War, South Korea was ruled by President Syngman Rhee from 1953 to 1960 , followed by a brief spell with a democratic government. The substantive catch-up project got off to a flying start under the regime of General Park Chung Hee, who was in power for almost two decades (1961-79).

Park's catch-up strategy can be characterized by a formula of "growth-first, distribution and stability later" (Jeon 1995, 72). The Park regime was founded on the coalition between the ex-military administrators and civilian technocrats on the one hand, and between the government and the large-scale conglomerates (chaebols) on the other. The catch-up strategy reflected Park's endeavors to legitimize the regime mainly through economic growth, while price stability and distributive measures were taken less seriously.

In the take-off phase from 1961 to 1973, South Korea's basic theme of state intervention was the making of an independent economy (Jarip Gyongje). The Economic Planning Board (EPB) controlled the budget and placed a strong emphasis on directing investment to achieve scale economies in targeted industries. Its policymakers were primarily concerned with "excessive competition", which would result in social waste. Therefore, lead firms were instructed to build plants of efficient production scale, which in turn compelled them to engage in global markets to avoid losses due to low capacity utilization (Chang 1993, 139-40). To control resource allocation, the government nationalized the commercial banks in 1961, exercising tight control over the lending activities until the early 1980s. This led to the use of "policy loans", which accounted for $57.9 \%$ of total bank loans made approximately between 1962 and 1987 (Heo 2001, 222). The second phase of catch-up (1973-79) focused on industrial deepening through the production of heavy and chemical industries (HCI). The regime expanded low-interest loans and relied heavily on deficitand-debt-financing and directed an excessive resource transfer from light to heavy industries.

Park's regime was increasingly authoritarian over time and ended with an assassination in 1979 amid growing political unrest. Ultimately, his growth-oriented strategy produced a sustained investment boom and resulted in rapid economic growth throughout the 1960s and 1970s. Yet, Park's single-minded quest for hyper-growth was accompanied by high inflation and an upward trend in income inequality. Overall, under the Park regime, annual per capita income was growing at $9.5 \%$, with an average inflation rate of around $15.5 \%$ (Jeon 1995, 73). However, inequality has increased over time, with the Gini coefficient rose from around 0.35 in the 1960s to $0.40-0.45$ from the 1970 s to the 1990 s (Solt 2009). ${ }^{2}$

\footnotetext{
${ }^{2}$ Income inequality figures are based on Frederick Solt, "The Standardized World Income Inequality Database," Version 3, http://hdl.handle.net/1902.1/11992 (accessed June 9, 2018), with a detailed description is in Solt (2009).
} 
Table 3.1 The chaebols' total assets compared with the government's fiscal budget (billions won)

\begin{tabular}{l|l|l|l}
\hline & 1980 & 1985 & 1990 \\
\hline $\begin{array}{l}\text { Sum of top four } \\
\text { chaebols }\end{array}$ & 8511 & 26,984 & 85,249 \\
\hline $\begin{array}{l}\text { Sum of top ten } \\
\text { chaebols }\end{array}$ & 14,592 & 38,718 & 127,292 \\
\hline $\begin{array}{l}\text { Sum of top thirty } \\
\text { chaebols }\end{array}$ & 21,800 & 54,914 & 167,655 \\
\hline $\begin{array}{l}\text { South Korean } \\
\text { government's fiscal } \\
\text { budget }\end{array}$ & 8648 & 15,000 & 32,537 \\
\hline
\end{tabular}

Source Summarized from Lim (2003)

\subsubsection{Winner and Losers in Structural Transformation}

Rapid industrialization has led to a dramatic change in the socio-economic structure. Industrial production, which accounted for $9 \%$ of the gross national product (GNP) in 1962 , increased to $31 \%$ in 1985 , while the share of agricultural production decreased from 43 to $15 \%$ (Koo 1991, 487).

South Korean catch-up strategy has created clear-cut winners and losers. In the private sector, resources have been concentrated within a small circle of chaebols at the expense of small enterprises. To support the chaebols, the state pushed the peasantry to become wage labor. Between 1955 and 1985, industrial-wage workers (in factories, mining, construction and transportation) increased from 5.9 to $25.7 \%$ of the labor force. They constituted the core of the emerging working class in South Korea, and by the mid-1980s they represented the largest occupational grouping. The middle class also flourished, with the proportion of professional, managerial and clerical workers increasing from 6.7 to $16.6 \%$ between 1963 and 1983 (Koo 1991, 485). Meanwhile, the total assets of the top 50 chaebols exceeded the governments' fiscal budget by approximately three times in 1980, four times in 1985, and six times in 1990 (see Table 3.1).

Along the industrialization path, it was labor who made the greatest sacrifice. Export-oriented strategy was based on low wages, with the state-sponsored labor union used to controlling workers and their wages. Legally, South Korean workers did not have the right to collective bargaining until 1987. However, with "neither the buffer of the agricultural economy nor the prospect of becoming small entrepreneurs" in sight (Chu 1998, 190), South Korean workers were inclined to appreciate collective movement as a realistic option to better their life chances. The continued militancy of South Korean unions originated from this long period of authoritarian exclusion and the absence of political parties to represent their interests (Lee 2011, 6). 


\subsubsection{Ongoing Confrontations, from the 1960s to the 1980s}

Popular resistance to the military regime, led by student groups and intellectuals, took place from the April Uprising in 1960 and continued to challenge Park's legitimacy throughout his regime. However, other sectors of civil society were largely dormant, due to an impressive economic performance and the regime's extensive surveillance (Kim 2000, 75). In the 1970s labor unions emerged as a major anti-government force, staging strikes for higher wages and better working conditions, in alliance with sections of civil society. Although the alliance was unable to force authoritarian departure, it generated a serious internal split within the ruling elite and ultimately led to critical junctures in the following decade (see Kim 2000, Ch. 4).

The confrontation became more intense from the late 1970s. After the assassination of Park, General Chun Doo Wan staged a military coup in December 1979 and became President from 1980 to 1988 . Following the slaughter of hundreds of people in the Gwangju Uprising in May 1980, Chun carried out a series of coercive campaigns to "cleanse" the entire civil society. In June 1980 the government arrested 329 politicians, professors, pastors, journalists and students. In July 1980 the military purged thousands of public officials, employees of public corporations, employees of agricultural and fisheries cooperatives, and teachers. In August 1980 the authorities arrested 16,599 "hooligans and gangsters" and sent them to military courts or labor camps (Kim 2000, 78-79).

\subsubsection{A Critical Juncture, 1984-1987}

The military succeeded in not only restoring political order but also rescuing the growth rate from $-3.7 \%$ in 1980 to $12.6 \%$ in 1983 . With politics and the economy under control, the military moved to pursue an appeasement policy from 1983 to 1984. It permitted 1,000 college and university students to return to their schools, pardoned 300 political prisoners and lifted bans on political activities for politicians and activists. Why so suddenly? Many studies attribute Chun's appeasement to his miscalculated confidence. However, Choe and Kim (2012, 59-60) pay more attention to timing and sequencing, pointing out that, for Chun, the appeasement policy appeared to be an inevitable political choice if the regime intended to shine in the forthcoming events, that is: the 1985 general election; the 1987 presidential election; and hosting the 1986 Seoul Asian Games and the 1988 Seoul Olympic Games-all of which were expected to heighten the political stature of the Chun regime in the shadow of the Gwangju massacre.

Nonetheless, contrary to Chun's expectations, rather than being satisfied with the relaxed measures, the former democratic alliance, together with the New Korea Democratic Party (NKDP) established in 1985, took this opportunity to threaten the regime's political stability. They began an active struggle, proposing constitutional 
revision for a direct presidential election. ${ }^{3}$ In the 1985 general election, the turnout reached $84.6 \%$, the highest since the 1950 s. With this agenda, the NKDP won $29.3 \%$ of the votes, slightly behind Chun's ruling Democratic Justice Party (DJP), which won $35.2 \%$, thus reinforcing the gathering momentum of pro-democracy movements (Kim 2000, 86).

In early 1987 civil society organizations and the opposition party formed a grand coalition that saw the triple solidarity of student groups, labor unions and religious organizations formed under the National Centre for Democratic Constitution ( $G u k$ bon). The nationwide demonstrations were aroused by the military's ongoing oppression of political dissenters, especially the killing of student activist Park Jong-cheol in January 1987, and Chun's decision to ban any discussion on constitutional revisions later in April (Lee 2011, 64-65). In June 1987 Chun's nomination of Roh Tae Woo as the DJP's presidential candidate triggered large pro-democracy rallies in Seoul and other cities. The demonstrations were critical enough to push Roh to announce the "June 29 Declaration" that covered eight points, the most important of which were a direct presidential election, the rehabilitation of political criminals, and the guaranteeing of media freedom.

The settlement in 1987 resulted from the intensification of street protests. As shown in Fig. 3.1, the number of protests rose sharply from 1984 to reach a peak in 1987. Between July and August 1987, approximately 3,000 strikes occurred, more than 12 times the number of strikes in the entire year of 1986 and quadrupling the number of strikes in 1980. Moreover, 1,278 new labor unions were created during the same period, which amounted to one-third of the total number of unions in existence at the end of 1987 (Kim 2000, 93). Yet, it is not just about number; the composition of the protesters also matters. Prior to 1987 street demonstrations had been the preserve of student activists and labor unions. There were no mass-rooted nationwide prodemocracy organizations until the founding of Gukbon, in which the middle class, salarymen and housewives took part in the central area of main cities (Lee 2000, 197). In sum, the military's political concession in the late 1980s was brought about by a series of contentious and dramatic confrontations.

\subsubsection{An Unfinished Transformation}

Despite military concession in 1987, the term "settlement" reflects South Korea's political development better than democratization since post-1987 politics has seen the continuity of the military's ruling party (DJP) and the fragmentation of prodemocracy forces.

To begin with, even with a free direct presidential election in December 1987, the pro-democracy forces did not win the race because of the internal split of their

\footnotetext{
${ }^{3}$ Until then South Korea had an indirect presidential election, or what many called the "gymnasium elections", in which members of the "national electoral college" gathered in a huge gymnasium and, irrespective of the genuine popular will, elected a president (Kim 2000, 85).
} 


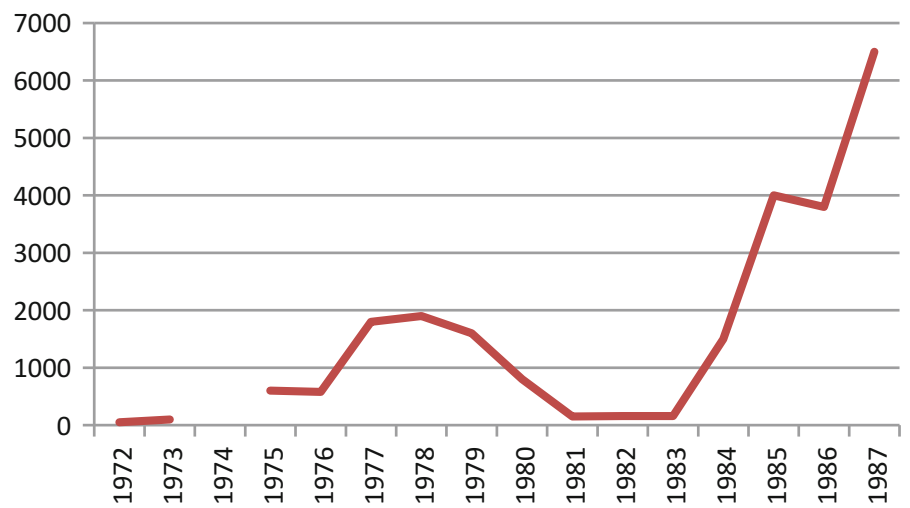

Fig. 3.1 Number of political protests from 1972 to 1987. Source Lee (2000: Fig. 2). No data on 1974

key leaders, known as the "two Kims" (see Kim 2000, Ch. 6). Advantaged by this fragmentation, DJP's Roh Tae Woo won the presidency with a 36.6\% vote, while Kim Young Sam and Kim Dae Jung received 28 and 27\% respectively. Roh's victory meant that South Korea's authoritarian elites survived and coexisted with the democratization process (Lee 2007, 111).

In addition to the political fragmentation that led to Roh's victory, the interests of social forces in South Korea seem to be divergent over time, making it difficult for more political consolidation. For much of the 1990s and the 2000s, South Korea was plagued by regional factionalism, labor-management conflict and right/left ideological cleavages (Kim 2003, 4). Of greatest concern seems to be regional divide. Im (2004) argues that, as soon as the country reached a general consensus on democratization in the late 1980s, voters lost their common agenda, Meanwhile presidential contenders tended to mobilize regional interests and sentiments for gathering votes. In the early 1990s regionalism deepened when the three parties merged to create a hegemonic regionalism designed to isolate minor regions. Some call it the "regional rivalry sentiment", while others point to urban concentration and an imbalance of regional development (see Choi 2009, 12-14), which have been the pitfalls of South Korea's successful catch-up.

The long legacy of authoritarian rule also left many people nostalgic for strong leadership, as seen in the case of Park Geun-hye, a daughter of General Park Chung Hee, who won the presidency in 2012 "thanks to older voters who remembered with fondness the regime of her father" (The Economist, 4 May 2017). Mass demonstrations returned in late 2016 against her alleged abuse of power. Lee Jae-yong, the son of Samsung's chairman, has also been involved in the scandal, accused of paying bribes in return for government support for corporate restructuring. However, early calls for Park Geun-hye to step down did not work until around a million protesters mobilized. Protests against Park Geun-hye are not just about disenchantment with the personnel; they also reflect a deeper frustration of the South Korean younger 
generation with an unlevel playing field in daily life. The US' Pew Research Center recently found that only $20 \%$ of young South Koreans were satisfied with the direction of their country, compared with four in ten of those aged fifty and over (The Economist, 4 May 2017). Although the presidential victory of Moon Jae-in in 2017 has brought hope of resolving the catch-up legacies, it is obvious that political settlement in South Korea takes much longer than its economic catch-up and is still very much in process.

\subsection{Taiwan and Gradual Opening}

In contrast to South Korea, Taiwan's catch-up strategy was driven by SMEs, while price stability and income equality were part of the initial plan. This strategy facilitated a gradual process toward political opening, largely under the control of the ruling leaders. Dominant studies in comparative politics typically portray Taiwan's political development as a top-down process under elite control. For example, Haggard and Kaufman $(2016,165)$ characterize it as the elite's "pre-emptive democratization". However, such a decision could not be made without a supportive context, especially the country's catch-up strategy and continuous local elections.

\subsubsection{Inclusive Growth with Political Reasons}

Taiwan's catch-up process was manned by the Kuomintang Party (KMT) and can be characterized as a "shared growth" model designed to achieve economic prosperity together with equitable distribution and a mild level of inflation. Its average growth was $9.7 \%$ from 1960 to 1980 , while Gini coefficient remained between 0.31 and 0.35 until the 1990s (Jeon 1995, 73).

This growth model is a calculated political move. The KMT attributed its defeat to the Chinese Communist Party in the civil war (1945-9) to a vicious cycle of social inequality, rampant inflation, intra-party factionalism and corrupt state-business ties. To avoid another political downfall, upon settling in Taiwan in 1949, the KMT began developmental state-building by a substantive land reform, which not only undermined local landlords but also allowed the party to gain legitimacy among agrarian smallholders (Lauridsen 2014, 434). The KMT later sought to maintain relatively tight fiscal and monetary policies, with surplus budgeting, high real interest rates, low money supply, and stable foreign exchange rates.

Taiwan helped its firms to develop technologies and open export markets through state agencies. That the KMT was considered an occupation force by the local Taiwanese population unintentionally benefited the catch-up process. Due to this political distance, local business interests could not influence state-led technology acquisition to favor particular groups at the expense of national interests (Khan and Blankenburg 2009). The KMT was also reluctant to allow native conglomerates to 
flourish, as they could threaten the party's dominance. As a result, most large-scale firms in the Taiwanese economy have been state-owned enterprises (SOEs), or rather "party enterprises", while the private sector consisted mainly of SMEs, with a few exceptions, such as the Tatung group or Formosa Plastic (Chang 2006, 117-18).

Taiwan entered the advanced phase of catch-up in the mid-1980s. The KMT introduced a comprehensive set of technology-upgrading policies and institutions. Favorable fiscal and financial incentives were granted to special public science and technology projects, as well as initiatives for private-sector technological development. Wong (1999) attributed Taiwan's success to its public research institute innovation network, involving the promotion of indigenous SMEs coupled with the large-scale development of public research institutes to facilitate technology assimilation/transfer and cooperative $R \& D$ promotion. Yet again, such industrial upgrading policies and dense public-private ties reflected the KMT's changing political strategy. As detailed in Lauridsen $(2014,438)$, the strong focus on high-tech industries was driven by the termination of the 1954 Mutual Defense Treaty, urging the KMT to move toward a more self-sustaining defense sector.

\subsubsection{Capital and Labor in Structural Transformation}

Successful catch-up in Taiwan led to rapid structural transformation. From 1956 to 1988 , the proportion of small farmers went down from 45 to $10 \%$, while manual workers rose from 20 to $45 \%$, and the middle class (professional, managerial and clerical workers) from $11 \%$ to more than $20 \%$ [collected from Burris (1992) and Koo (1991)].

However, compared to South Korea, Taiwan's catch-up strategy led to a different impact on the organization of social forces. In 1981 SMEs made up 55\% of non-agricultural production and employed $70 \%$ of the entire population in Taiwan (Lim 2003, 130). This structure facilitated the KMT's political domination. Until the 1980s several surveys found that 70-80\% of industrial and commercial associations supported the KMT, believing that the KMT not only provided the best guarantee of the social order required for business but also supported the broader interests of the private sector in economic development (Mcbeath 1998, 317).

Although Taiwan has a higher rate of unionization (22.3\% in 1986) than South Korea (7\% in 1986), labor unions in Taiwan had been largely under state control. No autonomous union existed before 1986, as local branches of the KMT were active in intervening in union activities or maintaining security offices inside large-sized factories (see Chu 1998). Moreover, the government's incentives did not favor large enterprises as in South Korea, but rather encouraged them to subcontract parts of their production to small firms. Thus, until the late 1980s many Taiwanese workers would regard factory jobs as an apprenticeship toward starting their own entrepreneurial careers. As a consequence, the political role of labor in Taiwan was less active and contentious than its South Korean counterpart. Although the number of labor 
disputes increased markedly during the 1980s, there were rare large-scale industrial demonstrations. It was after the rescinding of martial law in 1987 that workers began to get organized (Chu 1998, 192).

\subsubsection{Continuity of Local Elections}

Despite maintaining a tight grip on the national polity and economy, elections have been held continuously at local districts, laying a firm foundation for competing forces to negotiate on political opening at the national level.

To strengthen its legitimacy as much as its control across regions, the KMT continued to expand the scope of local elections from the 1950s. The KMT also used local elections to identify authentic local leaders and co-opted them into the party. From 1951 the Taiwanese could cast their votes for the Provincial Assembly, along with elections for village executives and councils, on a regular basis and without significant interruption. Independent candidates were permitted to run in the competition, but KMT candidates tended to win, with the help of the single non-transferable vote and multi-member district electoral system (SNTV-MM system) that undermined the chances of independent candidates (Wong 2001, 343).

Despite the KMT's manipulation, a close study by Rigger (1999) found that grassroots elections were a powerful process for political socialization in Taiwan. By the early 1980s, opposition and independent candidates had already played the electoral game for nearly 30 years. The experience of voting in competitive local elections encouraged the Taiwanese to express their preferences and focus on party identification. Meanwhile, the opposition forces could use local elections to develop their skills of political mobilization. Accordingly, the continuity of local-level elections provided an effective institutional infrastructure for full-blown democratization in the later period, as it "created and reinforced party identification, which made retreating from reform doubly difficult" (Rigger 1999, 181).

\subsubsection{Elite Bargains in the 1980s}

The contexts of shared-growth catch-up and continuous local elections paved the way for elite bargaining in the process of gradual political opening. The three major power blocs that facilitated organized negotiations in the late 1980s were the KMT moderates, the opposition moderates and student protesters, with the hardliners in each bloc being marginalized (Fell 2012, 37).

As detailed in Huang et al. (1998), in the wake of the 1980 elections, one faction of the opposition, led by Kang Ning-hsiang, approached a group of reform-minded members of the KMT and initiated a consultative meeting with opposition leaders. And from 1981 KMT soft-liners and leaders of the Tangwai (meaning "outside the party") started arranging informal meetings, in which opposition leaders gave 
the impression that they were willing to work with the KMT in facilitating democratic transition. Political persecution did continue in the 1980s but less severely than before. An important milestone came in September 1986 when the Tangwai formally founded the Democratic Progressive Party (DPP) to contest the year-end supplementary elections. Although technically illegal, the KMT allowed the DPP to run its first election campaign in December 1986 and won 12 legislative and 11 National Assembly seats-which could be counted as Taiwan's first multi-party election at the national level (Fell 2012, 33).

Whether Chiang Ching-kuo-KMT leader from 1978 to 1988 - was a true democratic reformer remains a debatable issue. However, note that Chiang Ching-kuo and the KMT allowed competitive national elections to take place only when they were confident that the party itself possessed sufficient organizational and political capabilities to prevail in a more competitive political setting (Haggard and Kaufman 2016, 165).

The martial law was lifted in July 1987, having been in operation for almost four decades. Moreover, in 1988 the KMT decided to choose Lee Teng-hui to be party chairman and ultimately president. This was an unconventional choice. The KMT had been led by mainlanders for almost four decades: Chiang Kai-shek (1950-75), Yen Chia-kan (1975-8) and Chiang Ching-kuo (1978-88). Lee was a native Taiwanese, US-educated technocrat who was the appointed Taipei City mayor from 1978 to 1981. This selection suggested that reformist leaders in the KMT were beginning to realize that the party's reputation as a "mainlander redoubt" was a political liability, indicated by the overwhelming success of Taiwanese candidates in elections and the increasing popularity of the opposition party throughout the 1980s (Rigger 1999, 122).

A series of gradual political openings arose under the presidency of Lee Tenghui (1988-2000). In March 1990 President Lee announced his intention to host the National Affairs Conference (NAC), bringing together elites from both the ruling and opposition camps to negotiate, bargain and forge compromises on the country's key issues. The NAC marked the first time that politicians from both parties formally met to hammer out extremely sensitive political projects (Wong 2001, 350). Again, it is worth noting that the NAC did not merely result from the elite's decision. Rather, it came from the demands of students and intellectuals, who arranged the socalled Wild Lily student movement, an unprecedented 22,000-strong demonstration in Taipei, from 16 March until Lee's presidential inauguration on 21 March 1990 (Chao and Myers 1998, 192).

\subsubsection{Gradual Political Opening from the 1990s}

The NAC marked a critical juncture in Taiwan's political development. It brought formerly exiled or jailed dissidents face-to-face with the KMT leaders who had exiled or jailed them. More importantly, it set an agenda for political reform, which would be followed even though the NAC had no statutory force (Huang et al. 1998, 153). 
Most of the reforms discussed at the NAC were enacted. National Assembly elections in 1991 and legislative elections in 1992 featured full-scale electoral and free-party competition. March 1996 saw the direct presidential election, which was sufficiently freely contested for the Freedom House to rank Taiwan as a "politically free" country for the first time (Huang et al. 1998, 148).

A next step in the political development of Taiwan was the creation of the National Development Conference (NDC), an extra-constitutional forum, in December 1996. The NDC consisted of 170 representatives from all of the important sectors of society. At the end of the NDC, Lee Teng-hui reached a new position, from which he could lead the KMT beyond its founders and previous legacy, while the DPP's leaders learned to play the game of electoral and legislative politics successfully and to contain their party's ingrained factional struggles (Huang et al. 1998, 159-60). With the NDC's key resolutions becoming part of the revised Constitution, Taiwan entered 1997 with considerable consensus over the country's key issues of relations with China and the rules of the political game (Jacobs 1997, 155).

The DPP eventually won a presidential election in 2000 thanks to its social welfare policies and a split within the KMT. However, President Chen Shui-bian (2000-8) and the DPP had lost its popularity over time due to various reasons. As detailed in Lauridsen $(2014,441)$, the facts that economic bureaucracy was still KMT-dominated while the DPP itself could not win the majority in the Parliament caused several cases of policy paralysis under Chen's tenure. Meanwhile, the lack of a direct mode of financing (such as KMT's party enterprises) incentivized the DPP to distribute giveaway subsidies to favored firms, leading to corruption and embezzlement, on which Chen and his wife were convicted in 2009.

Despite the fall of the DPP in 2008, Taiwan's contemporary political economy is generally open and inclusive. From 1996 until 2016, the Freedom House rated Taiwan as a "free" country, with high scores on both political rights and civil liberties, generally a step higher than South Korea. ${ }^{4}$ There is an increasing tendency toward a healthy two-party system in which, after the introduction of a direct presidential election in 1996, the government has alternated between the KMT (in office 1996-2000 and 2008-16) and the DPP (2000-8 and 2016-present).

\subsection{Singapore and Continuous Consolidation}

Although South Korea and Taiwan have taken varying paths to socio-political settlement, both have ended up with a generally democratic procedure. In this respect, Singapore's path has been fundamentally different. Until the mid-1990s, Levitsky and Way (2010: 34) considered Singapore to be a "fully authoritarian" regime because "restrictions on speech and association made it nearly impossible for opposition groups to operate publicly and because legal controls and other institutional obstacles prevented opposition parties from contesting most seats in parliament". Even in

${ }^{4}$ https://freedomhouse.org/report/freedom-world/freedom-world-2017. 
2017, when the country has a per capita income of USD 52,889, making it the world's tenth richest country, the Freedom House still counts Singapore as being "party free". A general election may be fully contested, but television and the traditional media are "mostly aligned with the ruling People's Action Party", ${ }^{6}$ facilitating the party to capture $93 \%$ of the seats and $70 \%$ of the popular vote in 2015. Put together, this chapter characterizes Singapore's path to settlement as continuous consolidation.

\subsubsection{Stable Growth with Peculiar Compositions}

Singapore's catch-up strategy can be categorized as a "stable growth" model, in which the emphasis was placed on economic growth together with political and macroeconomic stability, but relatively less on income distribution. Singapore grew at an average rate of $10.2 \%$ between 1965 and 1979, with its Gini coefficient reducing from 0.50 (1965) to 0.43 (1980) and 0.41 (1990) (Jeon 1995, 75 and Solt 2009).

Singapore adopted a free-trade regime and strongly supported foreign direct investment (FDI), making its industrial policies distinct from other East Asian countries. Even so, Singapore did not pursue a laissez-faire approach, as usually assumed. Although adopting a pro-FDI approach, the Singaporean government has worked hard to attract FDI into strategic areas by investing in particular types of manpower and infrastructure, as well as providing custom-designed financial incentives (Chang 2006, 118). More importantly, the government set up SOEs, known as governmentlinked corporations (GLCs) across key industrial sectors, including Singapore Airlines, telecommunications, financial services, energy and natural resources, transport, shipping, semiconductors, health care and engineering. As a result, the public sector share of gross fixed capital formation in Singapore was 35.6\% in the 1960s, 26.7\% in the 1970s and 30.3\% in the 1980s, much higher than in Taiwan and South Korea (see Shin 2005). Singapore often used these GLCs to pump-prime the economy whenever there was any sign of economic downturn, while profits from GLCs were used to subsidize deficits in government priority areas such as housing (Chowdhury 2008).

In sum, Singapore's successful catch-up was driven by a "peculiar" policy mix of free trade, pro-FDI with custom-designed incentives, and heavy use of SOEs. This resulted in an annual growth rate of $10.2 \%$ and an inflation rate of $4.3 \%$ between 1965 and 1979 (Jeon 1995, 73).

\subsubsection{Tying the PAP-Bureaucracy Nexus}

The above catch-up strategy had been crafted and carried out by the People's Action Party (PAP), which has ruled Singapore since its independence in 1959. The PAP

\footnotetext{
${ }^{5} \mathrm{http} / / /$ freedomhouse.org/report/freedom-world/2017/singapore (accessed 17 May 2017).

${ }^{6} \mathrm{http}: / /$ freedomhouse.org/report/freedom-world/2016/singapore (accessed 17 May 2017).
} 
has been led by three prime ministers: Lee Kuan Yew (1959-90); Goh Chok Tong (1990-2004); and Lee Hsien Loong (2004-present).

The PAP had a landslide victory in the 1959 elections. Initially, social tensions surrounding the issue about a merger with the Federation of Malaysia in the early 1960s encouraged PAP leaders to intimidate its opponents, particularly trade unions, journalists and student leaders. For example, in the particular swoop in 1963, 111 people were arrested under the Internal Security Act (ISA), legislation inherited by the British and giving the authorities the power of detention without trial. However, over time, the PAP has developed a more nuanced approach to social organization. As detailed in Rodan (2006), it began by strengthening ties between the party and public bureaucracies. Policy formation was completely removed from wider party organization and became a matter that was discussed only between the PAP executive, led by Lee Kuan Yew, and senior civil servants. New civil service appointments then extended PAP control over the state apparatus and, subsequently, the upper echelons of the civil service became the standard route to political leadership (Rodan and Jayasuriya 2009, 29).

Since then the state machinery has been part and parcel of the PAP's social organization. On the one hand, grass-roots para-political state institutions (e.g. People's Associations, Community Centres and Citizens' Consultative Committees) were initiated under the Prime Minister's Office. These organizations became avenues to foster support for the PAP's candidates and ideology. The most important achievement was the National Trades Union Congress (NTUC), through which the PAP fostered a political allegiance with selected elements of the working class (Rodan 2006, 7). On the other hand, the state set up strategic social schemes to reach more citizens, ranging from investments in education to public housing. The latter policy resulted in three-quarters of the Singaporean population living in apartments on 99-year leases from the government (Rodan and Jayasuriya 2009, 29). These schemes enabled the PAP to harness estate development and resettlement programmes during the 1960s and 1970s in an effort to dilute the electoral impact of political opposition (Rodan 2006, 8).

Another key mechanism used to tie the party-state nexus is manipulation of the electoral system. The institutionalization of authoritarian rule during the early $1960 \mathrm{~s}$ has had a number of long-lasting impacts. In the context of elections, the most debilitating tools included: the detention of opposition leaders; the denial of permits to hold campaign rallies; the shutting down of hostile printing facilities; increasing the candidate registration fee; limiting the campaign period to nine days; and placing the Elections Department within the Prime Minister's Office to facilitate the incumbent (Morgenbesser 2017, 8).

\subsubsection{New Industrial Revolution and Political Participation}

Since the mid-1980s, the government's successful attempt at the "new industrial revolution" has led to a surge of the middle class. The Singaporean middle class (defined 
as professionals, technicians and those employed in administrative and managerial work) increased from $10.3 \%$ (1970) to $13.6 \%$ (1980), $25.0 \%$ (1989) and then $40.3 \%$ (1999) (Tamura 2003). A steep rise after the 1980s was caused by government policies designed to train a large number of skilled workers required for industrial upgrading.

Accordingly, the PAP initiated new forms of political participation in response to the emerging middle class (Rodan 2006, 11-18). First, legal and administrative tools have become the PAP's essential mechanism to control opposing groups and the mass media. By design, the ruling party holds authority over appointments and renewal of the Supreme Court, as well as the transfers of lower court judges between judicial and government service. Regarding the media, amendments to the Newspaper and Printing Presses Act in 1986 have been instrumental in restricting the circulation of foreign publications.

Meanwhile, political participation has been encouraged through state-controlled channels. In the mid-1980s, the PAP established a group of extra-parliamentary units such as the Feedback Unit, under the Ministry of Community Development, to collate the public's response to policy issues. The Government Parliamentary Committee and the Institute of Policy Studies were also founded to incorporate professionals with specific policy expertise. Another significant step was taken in 1990, with constitutional revisions to create a new category of parliamentarians-Nominated MPs (NMPs) — to mediate the widening interests of Singaporean citizens, including domestic business, labor, women and ethnic organizations. Yet, the number and authority of the NMPs were decided by the PAP. For example, the NMPs were initially allocated with six positions with limited voting rights and gradually increased with the following elections.

Finally, economic dependence is also important. Much of the middle class was either employed by government departments and GLCs or received state services through the provision of professional legal, commercial or other assistance (Rodan and Jayasuriya 2009, 30). For example, from the 1980s to the 1990s more than $80 \%$ of Singapore's population lived in public housing built by the government's Housing Development Board (Tamura 2003, 191; Barr 2014, 33).

\subsubsection{Governance Ideology}

Approaching the 1980s, "technocracy" has become a new approach to legitimizing the PAP's domination, replacing the old paradigm of "pragmatism" that was powerful in the 1960s and 1970s. Technocratic governance was heralded by the introduction of professional, non-elected town councils helmed by local MPs to manage the delivery of services in the government's estates, in which the majority of Singaporeans lived. Under the concept of technocratic governance as a grand ideological theme, the PAP is adaptable to changes in broader contexts (Rodan 2006, 16-18). For example, when Asian economies were at their height in the 1990s, the government was keen to promote "Asian values". The implications of Asian values were that liberalism would create conflicts and would not be compatible with the Asian tradition of the 
consensual style of management. Yet, when the Asian financial crisis in the late 1990s delegitimized this discourse, the PAP was sufficiently responsive to shift toward a new idea of the "Singapore 21" vision, developed to forge a "partnership" between the government, the private sector and the people toward the common national interest.

A more practical application of technocratic professionalism is found in electoral regulations. That electoral laws have been manipulated to favor the PAP is well documented (see Tan 2013). However, the PAP never ceases to find a new "creative" way to undermine the opposition, as recently seen in the presidency, which since the 1990s has been an elected office vested with the power to veto any senior appointment in the civil service and Cabinet, including that of prime minister (Barr 2014). In January 2016 Prime Minister Lee Hsien Loong pushed forward a constitutional amendment to create stricter qualifying criteria for the presidency. It is now required that, to be president, one must have held, for no less than three years, one of several high offices - such as cabinet minister, Chief Justice, Speaker of Parliament, Attorney-General or Permanent Secretary. Alternatively, a person is qualified only if he or she has held the position of chief executive officer of a company with a paid-up capital of at least $\$ 100$ million (Lee 2016, 3). In effect, in almost every election, all alternatives to the PAP nominee have been ruled ineligible under these rules (Barr 2014, 34). This is because the PAP holds authority over appointments of almost all those positions through the government and the GLCs.

\subsubsection{A Prototype for High-Income Authoritarianism?}

The current Prime Minister Lee Hsien Loong, a son of Lee Kuan Yew, clearly stated that "a democratic system is inherently adversarial, and there are risks to it". ${ }^{7}$ Does this mean that Singapore is set to be a prototype for high-income authoritarianism?

The most recent election in 2015 saw the PAP's landslide victory, winning 69.9\% of the popular vote and 83 out of 89 parliamentary seats. It is possible that the PAP will retain its hold on power for the foreseeable future, underpinned by its political adaptability, as well as the existing institutional infrastructure. Meanwhile, research finds that opposition membership grew significantly in the 2000s, with a surge in young and well-qualified opposition candidates in their 20s and early 30 s in the 2011 and 2015 general elections (Singh 2012). In fact, the PAP was more responsive after the opposition's strong showing in 2011, leading Lee Hsien Loong to apologize for the ruling party's mistakes and to promise improvements. The PAP has since strengthened its community involvement and introduced more social programs to deal with citizen complaints. It also granted some political "opening", such as the relaxed measures that allow protests without police permits in a designated area, and political parties to use online media and videos during electoral campaigns $(\mathrm{Ng}$ 2016, 439).

\footnotetext{
7“Not Everything Debatable in Public”, Channel News Asia, 13 April 2011 (cited in Barr 2014).
} 
As Morgenbesser (2017) puts it, the PAP's source of stability lies in the art of balancing legitimation and repression-it always "encourages laws to be bent, not broken; media outlets to be regulated, not censored; public gatherings to be controlled, not outlawed; civil society organizations to be circumscribed, not eliminated; and elections to be managed, not blatantly stolen" (Morgenbesser 2017, 13).

\subsection{Concluding Remarks}

This chapter has pointed out that socio-political conflict is an integral part of catch-up and is worthy of more analytical consideration. It has also stressed the multiplicity of paths to settlement and how each path hinges heavily on the country's catchup strategy. This concluding section recaps the main findings and discusses some broader implications.

\subsubsection{Catch-up, Conflicts and Multiple Paths to Settlement}

In South Korea, the catch-up strategy led by General Park focused single-mindedly on industrial growth and created clear winners and losers. Resources were relocated to support the large-scale production of the chaebols in target industries. To force the ruling military into political concession, labor movements needed to ally with moderate civil society and middle classes to stage a series of contentious demonstrations. However, the rift within the pro-democracy forces extended the military's grip in the first direct presidential election in 1987. Subsequent politics in South Korea have continued to be shaped by confrontation and fragmentation.

The KMT learned from its political mistakes in mainland China and crafted Taiwan's catch-up in the direction of an inclusive growth model. On the surface, the KMT and the opposing forces seemed to reach a consensus to liberalize the political economy gradually from the late 1980s. However, such elite bargaining was made possible by an equitable development outcome, as well as the continuity of local elections in the background since 1950. Moreover, political opening through elite bargaining has also allowed the preservation of some authoritarian legacies, such as the KMT's control over state assets and the limited implementation of transitional justice (Fell 2012, 38).

In contrast to South Korea and Taiwan, where democracy has been the "only game in town" since the 1990s and witnessed an alternation of the ruling party, the PAP has managed to rule Singapore for almost sixty years since its independence. Right from the start the PAP has tied the party-bureaucracy nexus and undertaken social policies to render the emerging middle class heavily dependent upon it. The PAP has regularly adapted channels of political participation, as well as governance ideology, to suit the changing contexts. Table 3.2 summarizes these three paths to settlement in East Asia. 
Table 3.2 Comparing varieties of catch-up and settlement path in East Asia

\begin{tabular}{l|l|l|l}
\hline & $\begin{array}{l}\text { Catch-up } \\
\text { strategy }\end{array}$ & Development outcomes & $\begin{array}{l}\text { Path to } \\
\text { settlement }\end{array}$ \\
\hline South Korea & $\begin{array}{l}\text { Chaebol-led } \\
\text { growth }\end{array}$ & $\begin{array}{l}\bullet \text { Clear winners (chaebols, middle class) } \\
\text { and losers (labor, SMEs) } \\
\bullet \text { Increasing inequality }\end{array}$ & $\begin{array}{l}\text { Contentious } \\
\text { settlements }\end{array}$ \\
\hline Taiwan & Inclusive growth & $\begin{array}{l}\text { - SME-based economy } \\
\text { - Relatively equitable society } \\
\bullet \text { Strictly controlled labor }\end{array}$ & $\begin{array}{l}\text { Gradual } \\
\text { political } \\
\text { opening }\end{array}$ \\
\hline Singapore & $\begin{array}{l}\text { Free trade }+ \\
\text { strategic FDI } \\
\text { and SOEs }\end{array}$ & $\begin{array}{l}\text { Close ties between PAP-state-middle } \\
\text { class } \\
\text { Tight control over party politics and } \\
\text { participation }\end{array}$ & $\begin{array}{l}\text { Continuous } \\
\text { consolidation }\end{array}$ \\
\hline
\end{tabular}

\subsubsection{Broader Implications}

The findings herein differ from the conventional suggestion that a developing country needs a set of institutional prerequisites-especially a level playing field for new businesses and democracy - in order to sustain economic growth toward a high income level (Acemoglu and Robinson 2012; North et al. 2009). South Korea, Taiwan and Singapore have escaped the so-called "middle-income trap" despite their institutions being highly deficient in both the political and economic arenas. Even when South Korea and Taiwan democratized, they did so in an uneven and non-linear fashion. More interesting is the case of Singapore, which has hardly democratized at all by most standards. Settlement is therefore a better word than democratization to describe the way in which each society tries to manage the socio-political conflict arising from the rapid industrialization that changes the composition of class structures, as well as resource allocations.

The findings from this chapter may have different implications for the elite and non-elite in developing countries. The former may best look to Taiwan, while the latter could learn more from South Korea and Singapore.

The ruling elite typically considers Singapore to be the dream authoritarian, highincome destination, exemplified by the Chinese Communist Party's eagerness to follow the Singapore model (see Ortmann 2012). However, size does matter, while the absence of an agricultural sector makes it less difficult for the PAP to steer the economy in the way it has done. A relatively large country with a significant amount of agriculture needs a substantive land reform to reduce tensions at an early stage of industrialization. The ruling elite and policy-makers in today's developing countries should learn from Taiwan regarding the timing and preparation required for political concession and opening. A catch-up strategy that creates clear-cut winners and losers with no pre-emptive compensation, like that of South Korea, will heighten tensions over the course of development. A good growth strategy is one that comes with complementary policies to maintain price stability and income parity. In short, it is 
an inclusive development model that lays a solid foundation for the elite themselves in the bargaining process, as well as their survival in the post-authoritarian era. Unequal growth is inclined to arouse confrontation, which, in turn, impedes further economic restructuring at the later phase of catch-up - the Gordian Knot currently faced by countries like Thailand, Brazil and Turkey.

While the elite should learn from Taiwan, civil society and the citizens of developing countries may learn practical lessons from South Korea and Singapore. Political opening in South Korea has been driven mainly by labor unions-but they cannot achieve this without forming an alliance with civil society, students, religious organizations and parts of the middle class. After all, it is a cross-class coalition that makes the movement powerful. Moreover, Singapore also shows us that political opening could take place in various ways, even if such an opening were under state control. Civil society and social movements in other countries can make a pre-emptive move to demand Singaporean-style representation and participation, such as nominated MPs and the partnership consultation, before developing them into a more substantive channel such as Taiwan's National Conferences.

\section{References}

Acemoglu D, Robinson J (2012) Why nations fail: the origins of power, prosperity, and poverty. Profile, London

Amsden AH (1989) Asia's next giant: South Korea and late industrialization. University Press, Oxford

Barr MD (2014) The bonsai under the banyan tree: democracy and democratisation in Singapore. Democratization 21(1):29-48

Bellin E (2000) Contingent democrats: industrialists, labor, and democratization in late-developing countries. World Polit 52(2):175-205

Burris Val (1992) Late industrialization and class formation in East Asia. Research in Political Economy 13:245-283

Chang HJ (2006) Industrial policy in East Asia: lessons for Europe. EIB Papers 11(2):106-132

Chang HJ (1994) State, institutions and structural change. Structural Change and Economic Dynamics 5(2):293-313

Chang HJ (1993) The political economy of industrial policy in Korea. Camb J Econ 17(2):131-157

Chao L, Myers RH (1998) The first Chinese democracy: political life in the Republic of China on Taiwan. Johns Hopkins University Press, Baltimore, Md

Choe H, Kim J (2012) South Korea's democratization movements, 1980-1987: political structure, political opportunity, and framing. Inter-Asia Cultural Studies 13(1):55-68

Choi S (2009) Labor welfare in South Korea. J Workplace Behav Health 24(1-2):265-273

Chowdhury A (2008) Growth-oriented macroeconomic policies for small islands economies: lessons from Singapore. Research Paper No. 2008/47, UNUWIDER, Helsinki

Chu YW (1998) Labor and democratization in South Korea and Taiwan. Journal of Contemporary Asia 28(2):185-202

Di John J, Putzel J (2009) Political settlements. Discussion Paper, University of Birmingham

Evans P (1995) Embedded autonomy: States and industrial transformation. Princeton University Press, Princeton

Evans P, Rauch JE (1999) Bureaucracy and growth: a cross-national analysis of the effects of Weberian state structures on economic growth. Am Sociol Rev, 748-765 
Fell D (2012) Government and politics in Taiwan. Routledge

Fleckenstein T, Lee SC (2017) Democratization, post-industrialization, and East Asian welfare capitalism: the politics of welfare state reform in Japan, South Korea, and Taiwan. J Int Comp Soc Policy 33(1):36-54

Haggard S, Kaufman R (2016) Dictators and democrats: masses, elites, and regime change. Princeton University Press, Princeton

Heo Yoon (2001) Development strategy in Korea reexamined: an interventionist perspective. Soc Sci J 38(2):217-231

Huang TI, Tse-min L, Higley J (1998) Elite settlements in Taiwan. J Democracy 9(2):148-163

Im HB (2004) Faltering democratic consolidation in South Korea: democracy at the end of the 'three Kims' era. Democratization 11(5):179-198

Jacobs JB (1997) Democratisation in Taiwan revisited. Asian Stud Rev 21(2-3):149-157

Jeon JG (1995) Exploring the three varieties of East Asia's state-guided development model: Korea, Singapore, and Taiwan. Stud Comp Int Dev 30(3):70-88

Johnson C (1982) MITI and the Japanese miracle: the growth of industrial policy: 1925-1975. Stanford University Press, Stanford

Khan M, Blankenburg S (2009) The political economy of industrial policy in Asia and Latin America. In: Cimoli M, Dosi G, Stiglitz JE (eds) Industrial policy and development: the political economy of capabilities accumulation. Oxford University Press, Oxford

Khan M (2010) Political settlements and the governance of growth-enhancing institutions. SOAS Working Paper

Kim SS (2003) Korea's democratization. Cambridge University Press, Cambridge

Kim S (2000) The politics of democratization in Korea: the role of civil society. University of Pittsburgh Press, Pittsburgh

Koo H (1991) Middle classes, democratization, and class formation. Theor Soc 20(4):485-509

Kuznets S (1972) Innovations and adjustments in economic growth. Swed J Econ 74(4):431-451

Lauridsen L (2014) Governance and economic transformation in Taiwan: the role of politics. Dev Policy Rev 32(4):427-448

Lee JTT (2016) Singapore's elected president: an office that is still evolving. Paper presented at 16th international symposium on wearable computers, Newcastle, United Kingdom, 18-22 June 2012

Lee J (2000) Political protest and democratization in South Korea. Democratization 7(3):181-202

Lee S (2007) Democratic transition and the consolidation of democracy in South Korea. Taiwan J Democracy 3(1):99-125

Lee Y (2011) Militants or partisans: labor unions and democratic politics in Korea and Taiwan. Stanford University Press, Stanford, California

Levitsky S, Way LA (2010) Competitive authoritarianism: hybrid regimes after the cold war. Cambridge University Press, Cambridge

Lim S (2003) Chaebols and small and medium-sized capitalists: the forgotten players in Korean and Taiwanese democratization. Pac Focus 18(1):123-149

McBeath GA (1998) The changing role of business associations in democratizing Taiwan. J Contemp China 7(18):303-320

Morgenbesser L (2017) The autocratic mandate: elections, legitimacy and regime stability in Singapore. Pac Rev 30(2):205-231

$\mathrm{Ng} \mathrm{HY} \mathrm{(2016)} \mathrm{What} \mathrm{drives} \mathrm{young} \mathrm{people} \mathrm{into} \mathrm{opposition} \mathrm{parties} \mathrm{under} \mathrm{hybrid} \mathrm{regimes?} \mathrm{A} \mathrm{compar-}$ ison of Hong Kong and Singapore. Asian Politics Policy 8(3):436-455

North DC, Wallis JJ, Weingast BR (2009) Violence and social orders: a conceptual framework for interpreting recorded human history. Cambridge University Press, Cambridge

Ortmann S (2012) The 'Beijing consensus' and the 'Singapore model': Unmasking the myth of an alternative authoritarian state-capitalist model. J Chin Econ Bus Stud 10(4):337-359

Pak S (1998) Two forces of democratisation in Korea. J Contemp Asia 28(1):45-73

Rigger S (1999) Politics in Taiwan: voting for democracy. Routledge, London 
Rodan G (2006) Singapore exceptionalism: authoritarian rule and state transformation. Murdoch University, Asia Research Centre, Working Paper No. 131

Rodan G, Jayasuriya K (2009) Capitalist development, regime transitions and new forms of authoritarianism in Asia. Pac Rev 22(1):23-47

Rodrik D (2008) One economics, many recipes: globalization, institutions, and economic growth. Princeton University Press, Princeton

Shin JS (2005) Globalization and challenges to the developmental state: a comparison between South Korea and Singapore. Global Econ Rev 34(4):379-395

Singh B (2012) Politics and governance in Singapore: an introduction. McGraw-Hill Education, Singapore

Solt F (2009) Standardizing the world income inequality database. Soc Sci Q 90(2):231-242

Tamura KT (2003) The emergence and political consciousness of the middle class in Singapore. Dev Econ 41(2): 184-200

Tan N (2013) Manipulating electoral laws in Singapore. Electoral Stud 32(4):632-643

Wade R (1990) Governing the market: economic theory and the role of government in East Asian industrialization. Princeton University Press, Princeton

Wong J (2001) Dynamic democratization in Taiwan. J Contemp China 10(27):339-362

Wong PK (1999) National innovation systems for rapid technological catch-up. Paper at the DRUID Summer Conference on National Innovation Systems, Denmark, 9-12 June 1999

Open Access This chapter is licensed under the terms of the Creative Commons AttributionNonCommercial-NoDerivatives 4.0 International License (http://creativecommons.org/licenses/bync-nd/4.0/), which permits any noncommercial use, sharing, distribution and reproduction in any medium or format, as long as you give appropriate credit to the original author(s) and the source, provide a link to the Creative Commons license and indicate if you modified the licensed material. You do not have permission under this license to share adapted material derived from this chapter or parts of it.

The images or other third party material in this chapter are included in the chapter's Creative Commons license, unless indicated otherwise in a credit line to the material. If material is not included in the chapter's Creative Commons license and your intended use is not permitted by statutory regulation or exceeds the permitted use, you will need to obtain permission directly from the copyright holder.

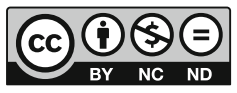

